\title{
Comparative Study of CdS and CdS/ZnS Thin Films Deposited by CBD as a Buffer Layer Solar Cell
}

\author{
A. García-Barrientos ${ }^{1}$, H. Gomez-Pozos ${ }^{2}$, E. Villicaña-Ortiz ${ }^{3}$ and L. Cruz-Netro ${ }^{4}$ \\ ${ }^{1 .}$ Faculty of Science, Universidad Autónoma de San Luis Potosi, SLP, México. \\ 2. Electronics Department, Universidad Autónoma del Estado de Hidalgo, Hidalgo, México. \\ 3. Departamento de Ingeniería de la Energía, Universidad de Ingeniería y Tecnología, Lima, Peru \\ 4. Ingeniería Industrial, Universidad Politécnica de Altamira, México
}

Cadmium sulphide (CdS) and Cadmium sulphide/Zinc sulfide (CdS/ZnS) thin films have been extensively investigated as an $n$-type buffer layer to form thin film heterojunction solar cells with $p$ $\mathrm{CdTe}$ absorber layers. The buffer layer affects the electrical properties of the junction and protects it from chemical reactions. From the electronic point of view, the $\mathrm{CdS}$ and $\mathrm{CdS} / \mathrm{ZnS}$ layers can optimize the band alignment of the device [1 and 2]. Also, these can build a sufficiently wide depletion width that minimizes tunneling and establishes a higher contact potential that allows higher open circuit voltage [2]. Recently, a particular attention of the researches has been focused on the heterostructures involving $\mathrm{CdS}$ and $\mathrm{CdS} / \mathrm{ZnS}$ multilayers [3]. Because of its band gap, it could be an excellent window layer in CdTe thin film solar cells. Since Chemical Bath Deposition (CBD) is known to produce solar cells over a large area at a low cost and low temperature. The effect of deposition parameters of $\mathrm{CdS}$ and $\mathrm{CdS} / \mathrm{ZnS}$ thin films developed by CBD technique were investigated in [4 and 5], principally, the influence of $\mathrm{pH}$ control of the reaction solution on the structural and optical properties of chemically deposited CdS and $\mathrm{CdS} / \mathrm{ZnS}$ thin films. Different films thicknesses of $\mathrm{CdS}$ and $\mathrm{CdS} / \mathrm{ZnS}$ thin films were deposited onto a glass substrate. The structural surface morphology of as-deposited $\mathrm{CdS}$ and $\mathrm{CdS} / \mathrm{ZnS}$ thin films was characterized by SEM. The physical conditions were kept identical while growing of the samples. The investigation of the effect of the synthesis method on the change the ammonium hydroxide by buffer $\mathrm{pH}$ (from 10.1 - 13) contributed in increases the growth kinetics, resulting in thicker films.

In this paper, a comparative study of $\mathrm{CdS}$ and $\mathrm{CdS} / \mathrm{ZnS}$ thin films deposited by $\mathrm{CBD}$ as a buffer layer solar cell was carried out. The $\mathrm{CdS}$ and $\mathrm{CdS} / \mathrm{ZnS}$ thin films were fabricated by CBD technique on a glass substrate for a deposition time of 60 minutes at a bath temperature of $90{ }^{\circ} \mathrm{C}$. These thin films were synthesized by chemical bath deposition using acid as a complexing agent with $\mathrm{pH}$ values between 10.1 to 11.3 for the $\mathrm{CdS}$ thin films and for the $\mathrm{CdS} / \mathrm{ZnS}$ thin films with $\mathrm{pH}$ values between 11.4 to 13 , these can be seen in the Figures 1a and 1b, respectively. The SEM photos (see figure 1a) show the surfaces of $\mathrm{CdS}$ films grown at 60 minutes deposition time and to different solution $\mathrm{pH}$ values. Based on the optical transmission measurements, the square of absorption coefficient $\left(\alpha^{2}\right)$ is plotted as a function of phonon energy $(\mathrm{h} v)$ in figure $1 \mathrm{c}$, one can see the energy band gap, $E \mathrm{~g}$, values $2.38,2.58$ and $2.44 \mathrm{eV}$ for $\mathrm{pH}$ values, $10.1,10.6$ and 11.3, respectively. In the other case, for the CdS/ZnS thin films grown at 60 minutes time deposition, one can see the SEM photos of the samples surfaces in the figure 1c. Also, we found different energy band gaps for different $\mathrm{pH}$ values; for $\mathrm{pH}=11.4, \mathrm{Eg}$ equals $2.74 \mathrm{eV}$ and at $\mathrm{pH}=11.8, E \mathrm{~g}$ equals $2.7 \mathrm{eV}$, these values are pretty similar of the literature [6]. Finally, these studies show that the $\mathrm{pH}$ contributes noticeably to the growth and to the structure of deposited $\mathrm{CdS}$ and $\mathrm{CdS} / \mathrm{ZnS}$ multilayer films. This may be interpreted by the decrease of the film thickness. From these studies, we are able to optimize the process in order to produce the layer suitable for optical window in solar cells. For the case of CdS thin films, it is better to use acid as a complexing agent with $\mathrm{pH}$ value equal to 10.6 and for the case of $\mathrm{CdS} / \mathrm{ZnS}$ thin films, it is better use with $\mathrm{pH}$ value equal to 11.4. This approach could be used in improving the spectral response of CdTe-based solar cells. A higher band gap was observed for $\mathrm{CdS} / \mathrm{ZnS}$, it indicates that there is clear short-wavelength advantages in current 
collection with the potential of increasing short-circuit current density for $\mathrm{Cd} / \mathrm{ZnS}$ compared to $\mathrm{CdS}$.

[1] Jongmin Kim, et al., Appl. Phys. Lett., vol. 102, no. 18, 183901, 2013.

[2] M.A. Contreras, Thin Solid Films, vol. 204, 403-404 pp., 2002.

[3] T. Ben Nasr, et al., Thin Solid Films, vol. 500, 4-8 pp., 2006.

[4] F.Vázquez-Monroy, et al. Metallogr. Microstruct. Anal., vol. 5, No. 62, 2016

[5] F. Vázquez-Monroy, et al., Microsc. Microanal., vol. 21, 295-296 pp., 2015

[6] Arreola-Jardón G., et al., Thin Solid Films, vol. 519, 517-520 pp., 2010

The authors acknowledge funding from the CONACYT-Mexico, research projects grant numbers 169062 and 204419.

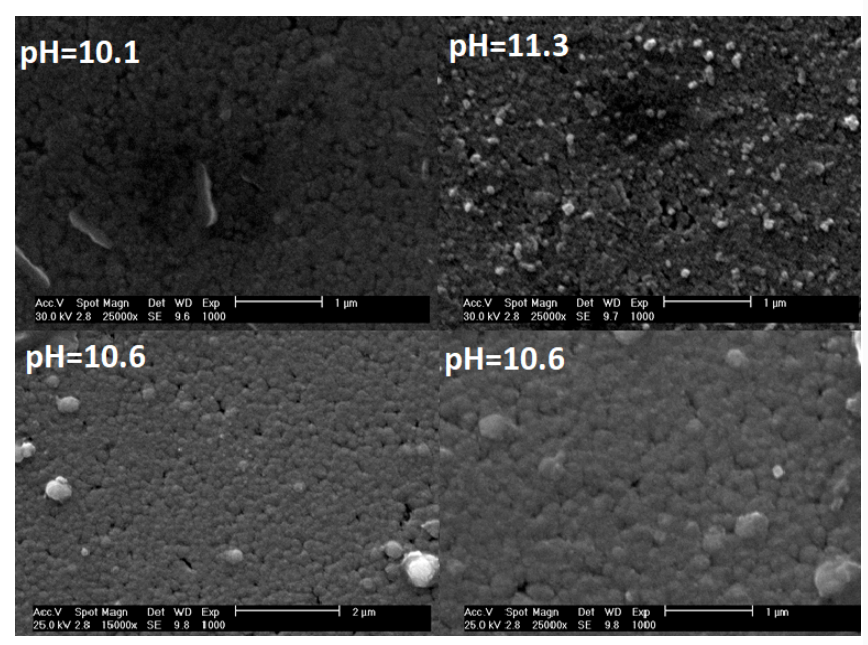

(a)

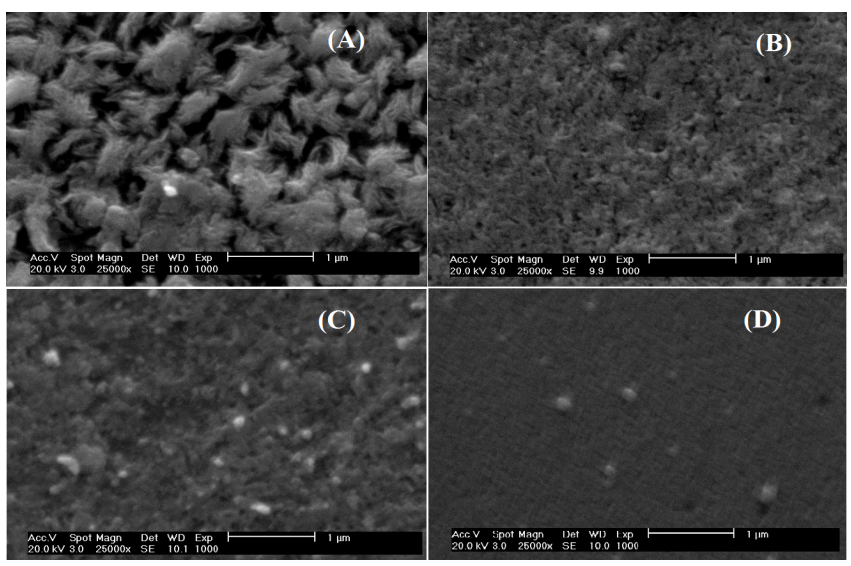

(b)

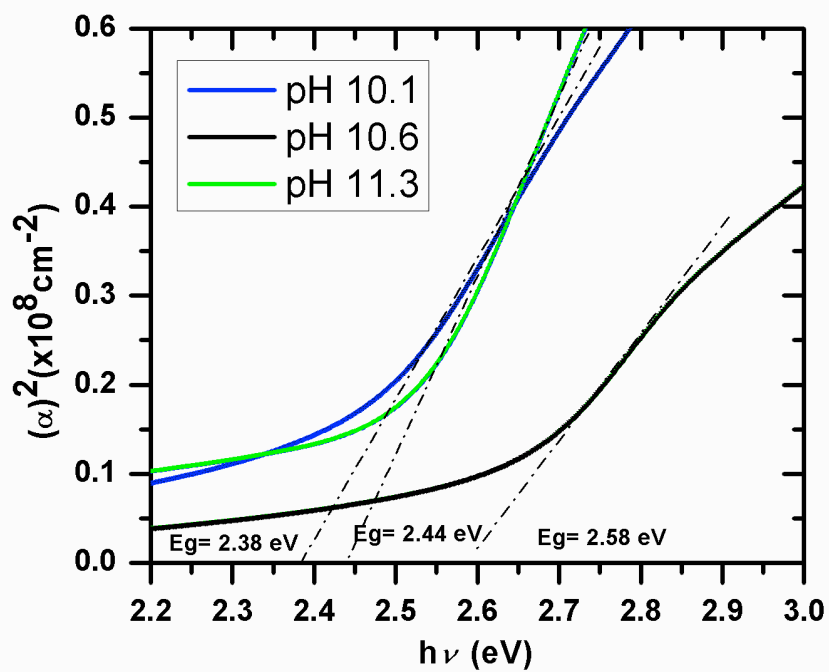

(c)

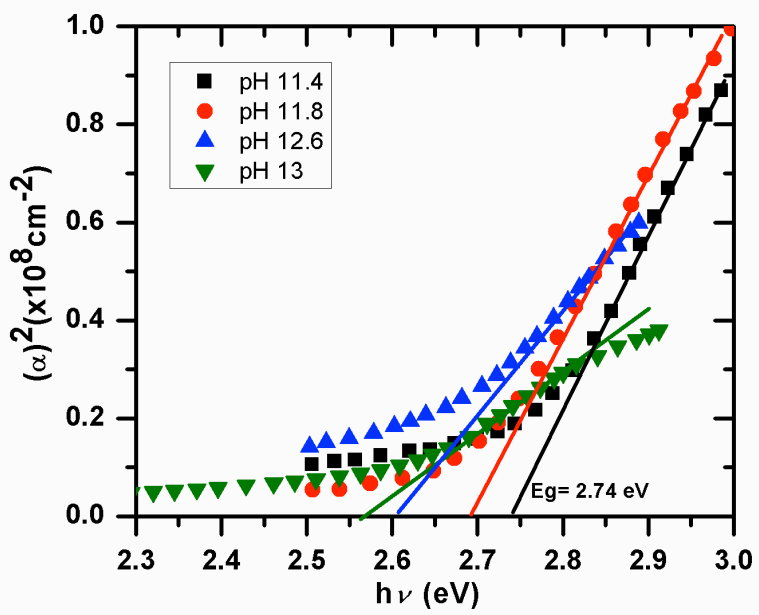

(d)

Figure 1. SEM photos of the samples surfaces of CdS thin films (a) and $\mathrm{Cd} / \mathrm{ZnS}$ thin films (b) grown at 60 minutes time deposition to different solution $\mathrm{pH}, \mathrm{A}: 11.4, \mathrm{~B}: 11.8, \mathrm{C}: 12.6$ and D:13. $\alpha^{2}$ versus hv plot for $\mathrm{CdS}$ thin films (c) and for $\mathrm{CdS} / \mathrm{ZnS}$ thin films (d). 